\title{
Light spectrum and indolebutyric acid (IBA) in rhizogenesis in herbaceous cuttings of guava trees
}

\begin{abstract}
Background: In the production of seedlings, success in the market is due to a quality product. Well-developed seedlings with a good root system, appear as a key factor to guarantee suitable products. Light can be used as a stimulating factor for rooting, in adequate light quality. Photoselective screens can be used to make rooting more efficient.

Methods: To evaluate this factor, herbaceous cuttings of Guava Tree "Paluma" were used, exposed to different wavelengths in mini-greenhouses covered with cellophane of the colors: green, yellow, red, blue, transparent and orange, and subjected to five treatments with Indolebutyric Acid (IBA) $(0,1000,2000,3000$ and $4000 \mathrm{mg} . \mathrm{kg}-1)$, grown in a 3: 2: 1 substrate (sand: earth: bioplant $($ ), in a randomized block design, with a $6 \times 5$ factorial and four replications with 10 cuttings in each treatment. Ninety days after staking, the following variables were evaluated: cuttings survival, number of leaves; number of sprouts; largest sprout length; root length; root volume; green mass of leaves and root; dry mass of sprout and root.
\end{abstract}

Results: The orange and red light spectra were superior in rooting the guava cuttings, and may be an option in covering the seedling production nurseries of this fruit tree.

Conclusion: The use of IBA neutralized the luminous influence of the light spectra with non-significant results for the interaction.

Keywords: rooting, wavelength, vermiculite, greenhouses, fotosseletoras, paluma
Volume 8 Issue 5 - 202I

\author{
Hérica Chisté, Marcus Vinicius Sandoval \\ Paixão, Loren Chisté José Matias Gomes, \\ Edilson Romais Schmildt, Antonio Resende \\ Fernandes \\ Instituto Federal do Espirito Santo Agronomia, Argentina
}

Correspondence: Marcus Vinicius Sandoval Paixão, Instituto Federal do Espirito Santo Agronomia,Argentina, Emailmvspaixao@gmail.com

Received: April 13, 2021 | Published: October 18, 2021

\section{Introduction}

The Guava (Psidium guajava L.) belongs to the class Dicotyledoneae, order Myrtiflorae, suborder Myrtineae, family Myrtaceae, genus Psidium and species Psidium guajava L. Its great economic importance is seen mainly in tropical and subtropical regions of the planet, with emphasis on its sensory properties and nutritional values, with considerable levels of vitamins $\mathrm{A}, \mathrm{B}$, and $\mathrm{C}$ such as thiamine and niacin being considered the richest fruit in zinc, fibers, vitamin $\mathrm{E}$ and lycopene. ${ }^{1}$ Brazil is among the largest producers of red guavas, with a planted area of over 15 thousand hectares and a production of 300 thousand tons/year. ${ }^{2,3}$

The propagation of plants through stem cuttings is based on the tissue's ability to regenerate to form roots. In turn, the formation of adventitious roots depends on natural or induced conditions of the parent plant, such as water status, temperature, and local relative humidity, light (irradiance, quality and photoperiod), $\mathrm{CO}_{2}$, nutrition, pruning, and accumulation of reserves. ${ }^{4}$

Vegetative propagation is an old technique that is based on the totipotency of plant cells, where each living cell of a plant has enough genetic information to originate an entire plant. ${ }^{5}$ In this propagation, the plants are obtained from a propagule taken from the matrix plant, consisting only of somatic cells. Propagation by somatic cells is an alternative for producing seedlings on a large scale with short intervals of time, which will provide homogeneous crops in productivity and quality, precocity and tolerance to phytopathogens. ${ }^{4}$

The importance of the production of guava seedlings by cutting, is in the maintenance of the genetic characteristics of the mother plant, with desired qualities and precocious production, factors desired in the production of seedlings on a large scale for commercial production.

Guava is a crop demanding heat and light to develop and produce well, factors that directly influence the photosynthesis of the plant. Light is one of the environmental factors to which plants are constantly exposed, in addition to light being important for the production of energy for photosynthesis, it is also used as a source of information about the environment to which they are inserted. ${ }^{6}$

The guava plant can be reproduced by cuttings, and its propagation needs special practices to facilitate its rooting. In this way, the use of different light spectra can create special conditions for rooting and producing a better quality seedling. Knowing the best light spectrum, which will favor the rooting of cuttings, can be a great advance in the production of cuttings by cuttings to facilitate the rooting of cuttings. ${ }^{6}$

Although propagation via cuttings is an effective method, the rooting of guava cuttings can be hampered by several factors, such as the environment that is inserted, those related to the plant itself, the use of hormones, and methods of conducting seedlings.

One of the factors that limit the formation of adventitious roots is the plant's characteristics, such as age, genotype, and nutrition of the plant where the cuttings will be removed. ${ }^{4}$ The use of indole butyric acid (IBA) can act to help the rooting of the cuttings, because their biosynthesis occurs in cell division sites, being able to mention the apical buds, young leaves, developing fruits and seeds, with translocation in a basic form for the collection and acropolis for the roots. ${ }^{6}$ The objective of this study was to evaluate the effect of the light spectrum on the rooting of herbaceous cuttings of guava trees 
(Psidium guajava L.) and the interaction of this variable with the use of IBA as a stimulus for the rooting of cuttings.

\section{Material and methods}

The experiment was conducted in the seedling nursery in the nursery sector of the Federal Institute of Espírito Santo (IFESCampus Santa Teresa), from February 2017 to May 2017, located in the mesoregion Central Espírito-Santense, in the municipality of Santa Teresa-ES, with geographical coordinates of 19 56 ' 12 "S and $40^{\circ} 35^{\prime} 28^{\prime \prime} \mathrm{W}$, altitude of $155 \mathrm{~m}$. The region's climate is characterized as Cwa, mesothermal, with a dry season in winter and heavy rainfall in summer (Köppen classification) ${ }^{14}$ with an average annual rainfall of $1,404.2 \mathrm{~mm}$ and an average annual temperature of $19.9^{\circ} \mathrm{C}$, with maximum $32.8^{\circ} \mathrm{C}$ and a minimum of $10.6^{\circ} \mathrm{C}$.

Herbaceous cuttings of guava from the cultivar "Paluma" were used as propagules in the experiment, obtained from non-lignified young branches. After preparing the propagules, the cuttings were immediately placed for rooting, in mini-greenhouses covered with cellophane of different colors: blue; green; yellow; orange; red; transparent, in polyolefin screen with $50 \%$ shading, in a randomized block design with six light quality treatments and five IBA treatments, $1.000 \mathrm{mg} \cdot \mathrm{Kg}^{-1}, 2.000 \mathrm{mg} . \mathrm{Kg}^{-1}, 3.000 \mathrm{mg} . \mathrm{Kg}^{-1}, 4.000 \mathrm{mg} . \mathrm{Kg}^{-1}$ and control without IBA, each with ten cuttings and four replications. The mini-greenhouses were made of wooden boxes, in the dimensions of $50 \times 50 \times 50 \mathrm{~cm}$ containing substrate in the proportion of 3: $2: 1$ (sand: soil: bioplant ${ }^{\circledR}$ ), and irrigation with nebulizers, timed with the aid of a timer, being the irrigation done for 15 minutes every hour.

At 90 days after staking, the following variables were evaluated: cuttings survival (Sc), number of leaves (NL); number of sprouts (NS); largest sprout length (SL); root length (RL); green mass of the aerial part (GMA); dry mass of the aerial part (DMA); green root mass (GRM); dry root mass (DRM). The experimental data were subjected to analysis of variance by the F test, meeting the model's assumptions by the Shapiro-Wilk test to verify normality and the treatment means compared by linear regression analysis and by the Tukey test at a 5\% level probability (Photo 1).

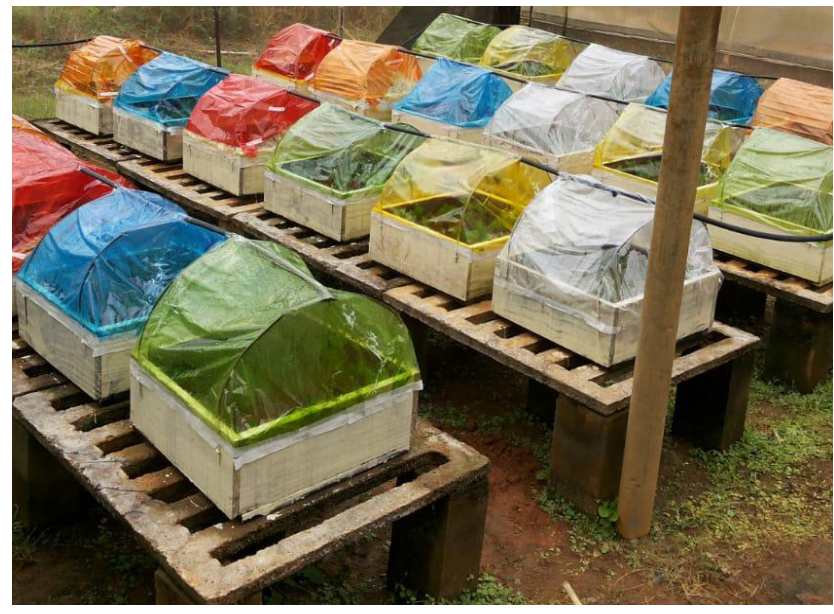

Photo I Setting up the experiment with mini greenhouses with colored cellophane.

Source:Author's photo.

\section{Results and discussion}

According to Table 1, it is observed that the red and orange light spectra, without the use of IBA, presented a higher survival rate with a statistical difference for the other spectra. Regarding the number of sprouts, no statistical difference was observed, but the length of the largest sprout showed a statistical difference with the yellow, orange, and red spectra showing values higher than the other light spectra. When evaluating the number of leaves, the yellow, orange, red and white light spectrum showed a statistical difference superior to the other light spectra, however, the root production did not present statistical difference between the treatments with different light spectra. All treatments related to the root = root length $(\mathrm{cm})$; green roots mass (g) and dry roots mass (g) (RL, GRM, and DRM) showed statistically equal values. This may have occurred due to the high rooting capacity of the cultivar "Paluma' 'and may be associated with its genetic, physiological, and metabolic characteristics.

Table I Rooting of guava cuttings without IBA in different light spectra

\begin{tabular}{llllllllll}
\hline Treat & SR & NS & SL & NL & RL & GLM & GRM & DLM & DRM \\
\hline White & $87 \mathrm{~b}$ & $1.20 \mathrm{a}$ & $10.34 \mathrm{~b}$ & $8.30 \mathrm{ab}$ & $22.33 \mathrm{a}$ & $1.127 \mathrm{~b}$ & $0.740 \mathrm{a}$ & $0.339 \mathrm{~b}$ & $0.144 \mathrm{a}$ \\
Green & $87 \mathrm{~b}$ & $1.20 \mathrm{a}$ & $10.99 \mathrm{~b}$ & $7.60 \mathrm{~b}$ & $22.90 \mathrm{a}$ & $1.199 \mathrm{~b}$ & $0.775 \mathrm{a}$ & $0.309 \mathrm{~b}$ & $0.160 \mathrm{a}$ \\
Yellow & $85 \mathrm{~b}$ & $1.20 \mathrm{a}$ & $12.32 \mathrm{a}$ & $9.25 \mathrm{a}$ & $24.82 \mathrm{a}$ & $1.535 \mathrm{a}$ & $0.952 \mathrm{a}$ & $0.429 \mathrm{a}$ & $0.186 \mathrm{a}$ \\
Blue & $90 \mathrm{~b}$ & $1.30 \mathrm{a}$ & $11.22 \mathrm{~b}$ & $7.95 \mathrm{~b}$ & $25.14 \mathrm{a}$ & $1.087 \mathrm{~b}$ & $0.85 \mathrm{a}$ & $0.305 \mathrm{~b}$ & $0.173 \mathrm{a}$ \\
Orange & $95 \mathrm{a}$ & $1.25 \mathrm{a}$ & $12.68 \mathrm{a}$ & $10.20 \mathrm{a}$ & $24.57 \mathrm{a}$ & $1.656 \mathrm{a}$ & $0.957 \mathrm{a}$ & $0.457 \mathrm{a}$ & $0.226 \mathrm{a}$ \\
Red & $95 \mathrm{a}$ & $1.10 \mathrm{a}$ & $12.90 \mathrm{a}$ & $9.55 \mathrm{a}$ & $24.02 \mathrm{a}$ & $1.408 \mathrm{a}$ & $0.74 \mathrm{a}$ & $0.397 \mathrm{a}$ & $0.185 \mathrm{a}$ \\
\hline
\end{tabular}

*Values followed by the same letter in the column are not differentiated by the Tukey test at a $5 \%$ probability level

*SR, survival rate (\%); NS, number of sprouts; SL, largest sprout length (cm); NL, number of leaves; RL, root length (cm); GLM, green leaf mass (g); GRM, green roots mass (g); DLM, dry leaf mass (g); MSR, dry roots mass $(\mathrm{g})$ 
The accumulation of starch in the cuttings during the rooting period may justify the rooting and the permanence of leaves in the cuttings may have maintained photosynthesis after staking, in addition to maintaining the flow of photoassimilates between the leaves and the base of the cuttings, providing greater maintenance of carbohydrates in the base. For the production of green and dry matter of the leaves, we can see in Table 1 that the treatments with the yellow, orange and red light spectrum showed statistically higher values, suggesting that these spectra were more efficient in photosynthesis, with greater production leaf area.

That 'Paluma' guava cuttings, derived from juvenile plants, showed $100 \%$ rooting. ${ }^{8}$ The high rooting capacity verified in the mentioned work may have occurred due to the youthfulness of the tissues, in which the age of the tissue interferes with the rhizogenic capacity of the cuttings. In this way, we can associate the youthfulness of the cuttings with the power of rooting in guava cuttings with responses in the quality and quantity of roots formed.

The light spectrum cannot be considered only as a primary source of energy through photosynthesis, in this case, it also acts in the development according to the proposed environment. Photosynthetically active radiation is located in the 400 to $700 \mathrm{~nm}$ range of the light quality spectrum, ${ }^{9}$ playing a fundamental role when photosynthesis, photomorphogenesis, and phototropism act in the growth and development of plants. ${ }^{10}$

Plants can perceive the quality, quantity, and direction of light and thus present physiological responses that interfere with their development, with the development of photoreceptors that act from the absorbed wavelength. Light is fundamental to root formation because it acts as an energy source for photosynthesis, however, high doses of luminosity activate the enzyme AIA-oxidase, auxin-degrading, which can reduce rooting. This fact indicates that we must practice rooting cuttings under low radiation, especially for species that have rooting difficulties. ${ }^{4}$ States that the effect of light on the rooting process may be due to the intensity and quality of the light, and the effect may occur directly on cuttings or parent plants. ${ }^{4}$

Light is a preponderant factor for root formation in cuttings, however, ${ }^{9}$ mention that the quantity and spectral quality of light, in balanced doses, are necessary to maintain a level of minimal endogenous auxins, while high levels of these light spectra can cause their photo destruction and adverse effects on the water relations of plants, in this work the light spectrum was not sufficient to increase the formation and production of roots in the spectra in which the leaf production was higher.

Plants obtain energy through the production of photosynthesis through light, a process in which plants can transform sunlight, water, carbon dioxide, and other nutrients into sugars (energy). Light plays a key role in photosynthesis, but other processes necessary for plant survival are also influenced by light, one of which is photomorphogenesis, which is a process of adapting the plant to the existing light conditions in the environment, the plant being will react differently to the incidence of light that is exposed. ${ }^{9}$

Most of the biological processes influenced by light, occur in the spectrum range called visible light, ranging from 400 to $700 \mathrm{~nm}$, where the main source of energy for photosynthesis is found in the ranges of visible light, with effects of this spectrum range can be observed in photomorphogenesis. ${ }^{11}$ Effects of different hormonal classes are all physiological events influenced by light and consequently, by the photoreceptors, these different hormonal classes are called auxin, cytokinin, gibberellin, abscisic acid, ethylene, and brassinosteroid.
In this sense, plant hormones or phytohormones are responsible for regulating stem elongation, seed germination, chlorophyll synthesis, flowering, and tuberization. ${ }^{11}$

When we evaluated the interaction between the light spectra and the application of IBA, we did not obtain a significant effect for the interaction, and when we performed the regression for the characteristics evaluated from the averages obtained from the light treatments, we observed significance only for the variables survival, sprout length, number of leaves and dry mass of leaves (Figures 1-9).

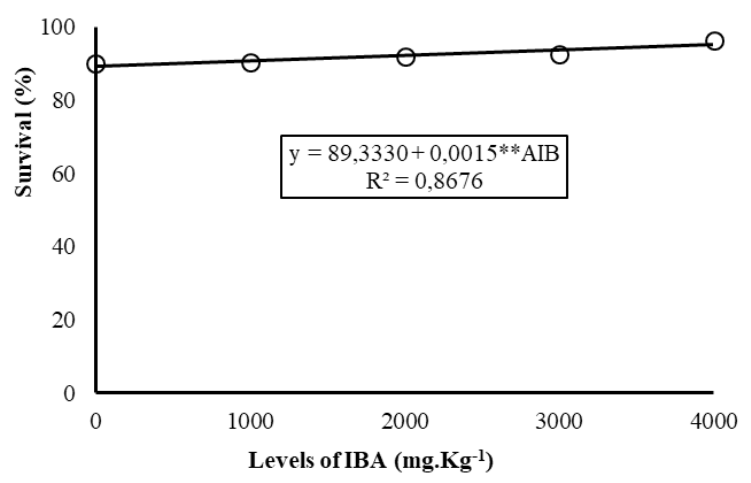

Figure I Survival rate at different IBA levels.

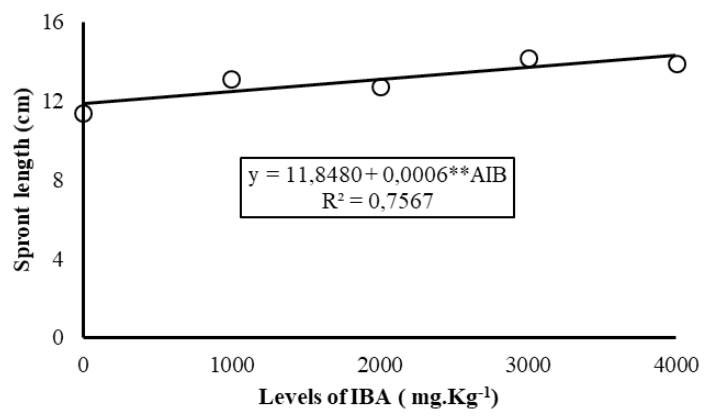

Figure 2 Length of the largest sprout at different IBA levels.

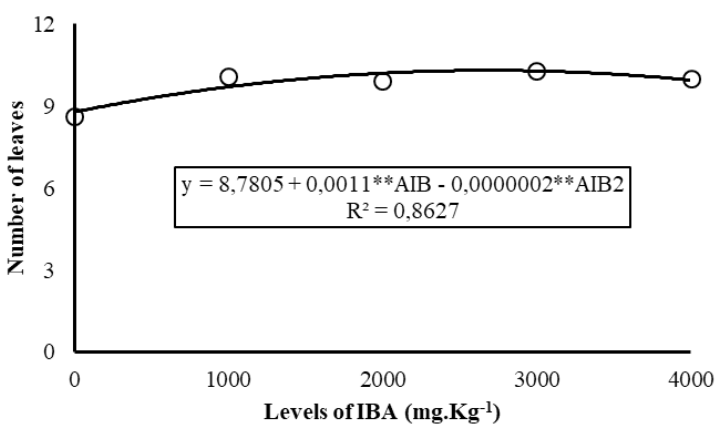

Figure 3 Number of leaves at different IBA levels.

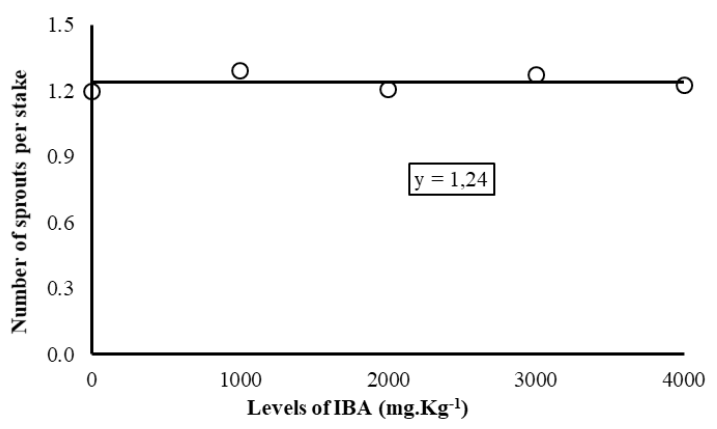

Figure 4 Number of sprouts at different IBA levels. 


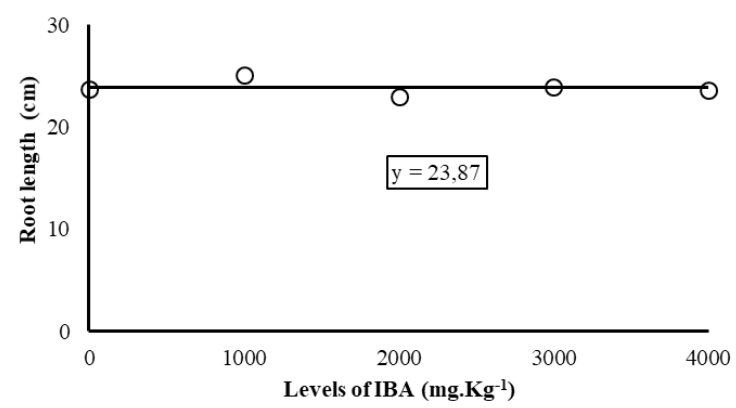

Figure 5 Root length at different IBA levels.

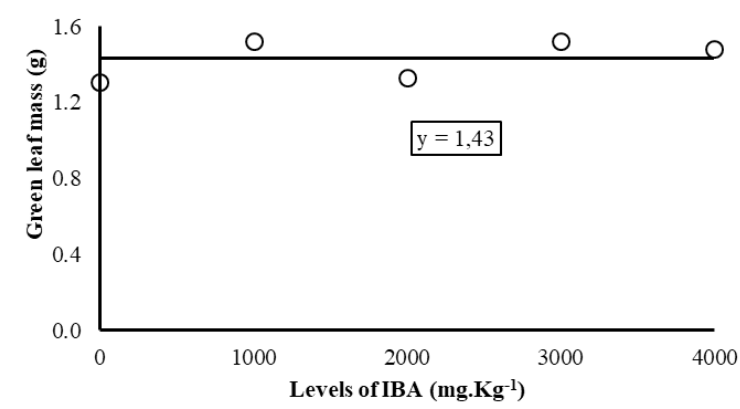

Figure 6 Green leaf mass at different IBA levels.

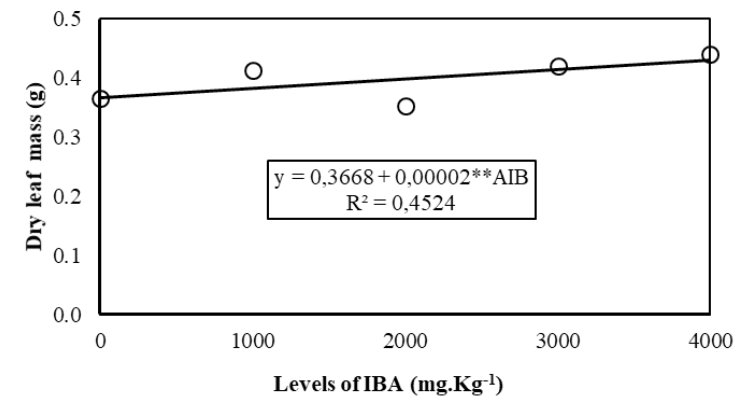

Figure 7 Dry leaf weight at different IBA levels.

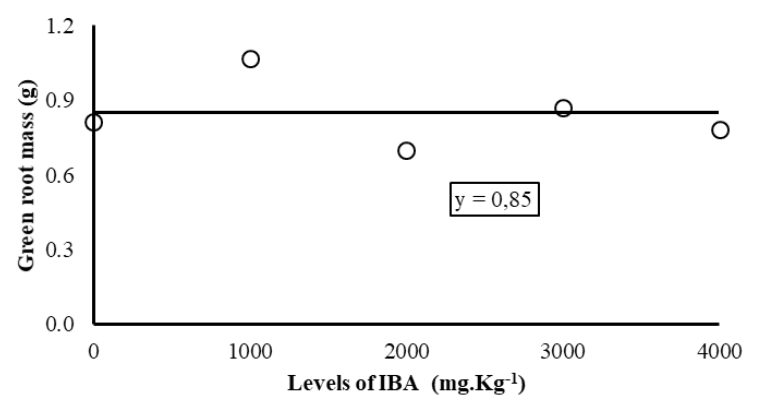

Figure 8 Green root mass at different IBA levels.

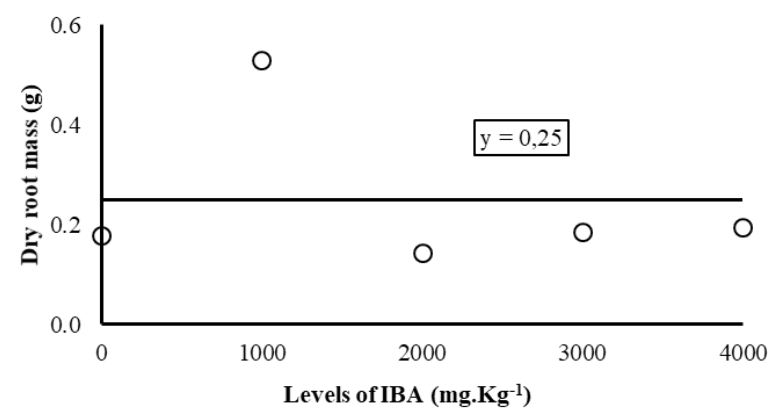

Figure 9 Dry root weight at different IBA levels.
The main phyto regulators involved in rooting are auxins and cytokinins that promote cell development by division; and the gibberellins that promote cell elongation, with the balance between the phytoregulators being the main factor responsible for the rhizogenesis in the cuttings. ${ }^{4}$ In this work the auxins did not act to improve the rooting of the cuttings, only the survival of the cuttings was significant and the variables related to sprout production were affected such as sprout length, number of leaves, and leaf dry mass. Auxins are hormones that also act in the emission of sprouts, in this work, probably the auxins used acted by stimulating sprouting since IBA showed improvements in the production of leaf mass. ${ }^{9}$ In research with IBA in guavas obtained positive results in the dosage of 2000 $\mathrm{mg} . \mathrm{L}^{-1}$ of IBA, in the characteristics related to the rooting percentage, the number, the length, and the dry mass of roots in herbaceous cuttings of Psidium guajava L. 'Century XXI'. ${ }^{12}$

There are several factors that act in the formation of roots, mentioning the period of rooting, concentration of the hormone, type of cutting as well as the genetic potential of the cultivar. They also mention that the release of phenolic compounds, in the place where the cuttings were cut, can act with the oxidation of the tissues and their darkening, making the formation of roots difficult. In this case, the Paluma guava did not show rejection to rooting or even showed signs of phenolic oxidation, however, the use of IBA did not act in a way that improved rooting, a fact that leads us to indicate that in this variety, the use of rooting inducers can be dismissed. ${ }^{13}$

\section{Conclusion}

The red, orange, and yellow light spectra were superior in rooting the guava cuttings and it might be an option for covering the seedling nurseries of this fruit tree.

The use of IBA neutralized the luminous influence of the different light spectra with non-significant results for the interaction.

\section{Acknowledgments}

None.

\section{Conflicts of interest}

There are no financial conflicts of interest.

\section{Funding}

None.

\section{References}

1. Ayd Mary Oshiro, Daiane Mugnol Dresch. Postharvest conservation of guavira (Campomanesia adamantium Camb.) under different coating and temperatures of storage. Revista Agrarian Dourados. 2011;4:294-302.

2. Vera Lúcia Ferraz dos Santos Francisco, Priscilla Rocha Silva Fagundes, Celma da Silva Lago Baptistella, et al. The guava culture in São Paulo. São Paulo: Agricultural Economics Institute, 2010.

3. Instituto Brasileiro De Estatística E Geografia- IBGE, Table 1613Quantity produced, production value, planted area and harvested area of permanent farming. 2010.

4. Hartmann HTL. Plant propagation: principles and practices. Boston: Prentice-Hall, 8.ed. 2011. 915 p.

5. Paixão MVS. propagation of plantas. 2 ed. Santa Teresa: Ifes, 2019. 230 p.

6. Taiz L, Zeiger E, Moller IM, et al. Physiology and plant development. 6 . ed. Porto Alegre/RS: Publisher Artmed, 2017. 888 p. 
7. Incaper. Planning and scheduling of actions for Santa Teresa. Technical assistance and rural extension program PROATER, Secretariat of Agriculture, 2011.

8. Marinho CS. Propagation of guava by minicutting. Revista Brasileira de Fruticultura. 2009;31:607-611.

9. Taiz L, Zeiger E. Fisiologia vegetal. 5 ed. Porto Alegre: Artmed. 2013. $954 \mathrm{p}$.

10. Antonopoulou C, K Dimassi, I Therios, et al. The influence of radiation quality on in vitrorooting and nutrient concentrations of peach rootstock. Biologia Plantarum. 2004;48:549-553.
11. Carvalho RF, Peres LEP. Fotomorfogênese - Escola Superior de Agricultura "Luiz de Queiroz". 2013.

12. Lilian Yukari Yamamoto Rogério de Sá Borges Mauren Sorace, et al. Enraizamento de estacas de Psidiumguajava L. 'Século XXI' tratadas com ácido indolbutírico veiculado em talco e álcool. Ciência Rural, Santa Maria. 2010;40:1037-1042.

13. Costa E, Gomes Va, Silva Pn, et al. Production of guava seedlings by cuttings in different containers and substrates. Agrarian Magazine, Gold. 2010;3:04-110.

14. Alvares Ca, Stape Jl, Sentlhas P, et al. Köppen's climate classification map for Brazil. Meteorologische Zeitschrift, 2013;22:711-728. 